\section{Estudo de recepção de impressos por trabalhadores da construção civil: um debate das relações entre saúde e trabalho}

\author{
Construction workers' reactions \\ to educational materials: a debate on \\ relations between health and work
}

Adriana Kelly-Santos 1

Brani Rozemberg 1,2

\footnotetext{
1 Escola Nacional de Saúde Pública Sergio Arouca Fundação Oswaldo Cruz, Rio de Janeiro, Brasil.

2 Instituto de Pesquisa Clínica Evandro Chagas, Fundação Oswaldo Cruz, Rio de Janeiro, Brasil.

\section{Correspondência} A. Kelly-Santos Escola Nacional de Saúde Pública Sergio Arouca, Fundação Oswaldo Cruz Rua do Riachuelo 119 apto. 210, Rio de Janeiro, $R \mathrm{~J}$ 20230-010, Brasil. adrianakelly@fiocruz.br
}

\begin{abstract}
This study focuses on the reactions of construction workers to educational materials (posters, folders, and leaflets) produced by the Brazilian Ministries of Health and Labor. The authors conducted two focal groups at construction sites in the city of Rio de Janeiro to analyze four educational materials, employing thematic analysis. The article presents the workers' perspective on the themes discussed in the leaflets, classified in two groups of meaning: health and social control. They go on to discuss how workers' display an expanded vision of health to the extent that it includes social determinants of the health-disease process. The study identified the workers' limited participation in work-process surveillance activities and their lack of knowledge concerning workers' health measures adopted by the Ministry of Health. The authors conclude that the analysis of educational materials by their target public represents a privileged place for negotiating meanings and grasping ways of life in specific groups. They suggest educational activities using leaflets as a means to motivate critical analysis of the health-disease process.
\end{abstract}

Broadsides; Occupational Health; Construction Industry

\section{Introdução}

A saúde do trabalhador é uma área de conhecimento e práxis da saúde coletiva. Caracterizase como uma vertente que introduz a discussão das relações entre trabalho/saúde/doença no campo das políticas públicas do setor saúde 1,2. Segundo esses autores, um dos pressupostos centrais dessa vertente é o da participação do trabalhador como um sujeito ativo nas transformações do processo saúde-doença relacionado com o trabalho.

As décadas de 1980 e 1990 marcam o período da implantação de Programas de Saúde do Trabalhador (PST), na rede de saúde pública, cujos objetivos são os de promover as ações de prevenção, de assistência, de recuperação e de promoção à saúde dos trabalhadores 3,4 . No processo de implantação da saúde do trabalhador no Sistema Único de Saúde (SUS), preconiza-se a participação do controle social no planejamento, execução e avaliação das propostas e projetos implementados; assim, para Spedo 4 (p. 75) "o controle social entendido como o exercício da cidadania, foi contemplado nessa proposta como requisito essencial à implantação da mesma, no sentido de assegurar as condições de acesso à informação e de democratização dos processos decisórios".

Em termos da dinâmica participativa dos atores de PST, consideramos a prática comunicativa por impressos um dos dispositivos dos 
processos comunicativos da saúde do trabalhador que pode subsidiar as reflexões acerca da participação dos trabalhadores nas ações dos PST.

No âmbito dos estudos de comunicação e saúde, adotamos o referencial dos estudos culturais 5,6 que privilegiam o lugar do sujeito na comunicação. Os autores discutem que a utilização e/ou produção de materiais educativos deve se pautar no processo de negociação de significados e na valorização de experiências entre profissionais de saúde e usuários dos serviços. Dessa forma, o discurso tecnicista e biomédico predominante pode ser indagado, por meio do diálogo crítico 7 pautado no processo comunicativo aberto que identifique interesses comuns entre os grupos, desenvolvendo uma intervenção fundada na promoção da saúde.

No campo da comunicação, reportamos aos estudos de recepção que problematizam o lugar do receptor-sujeito 8,9,10. Para esses autores, a "recepção é um espaço de interação" 10 (p. 57) e, os meios de comunicação são uma expressão de instâncias públicas que questionam e legitimam os espaços de produção de valores 9 . Por isso, torna-se importante considerar como componentes da recepção o modo como o emissor se posiciona, a concepção que cria de si mesmo e de seu receptor e a inter-relação estabelecida 11 .

No processo comunicativo emissor-receptor ocupam lugares distintos, porém, ambos são dotados de capacidades de produzirem sentidos frente às mensagens ofertadas. A vivência de uma situação de interlocução permite que emissor atue no lugar de receptor e viceversa ${ }^{8}$. Nesse processo há uma desregulagem comunicativa entre os interlocutores, pois emissor-receptor apresentam valores, crenças, costumes, modos de pensar e viver distintos que são colocados em confronto. Instituindo-se um espaço de negociação de sentidos, à medida que emissor e receptor interatuem como sujeitos que ressignifiquem suas histórias e conhecimentos, produzindo novos sentidos às mensagens em oferta 8,10 .

No cenário da comunicação e saúde investigamos 12 os processos comunicativos do PST, utilizando como mediação os impressos (cartazes, folhetos e cartilhas) produzidos pelo Ministério da Saúde e Ministério do Trabalho e do Emprego. Objetivamos oferecer subsídios teórico-metodológicos para que o campo da saúde do trabalhador possa aprimorar suas reflexões e ações no âmbito dos processos comunicativos em suas práticas e debates referentes ao binômio saúde-trabalho, junto à população. Triangulamos os seguintes métodos: análise documental, entrevistas semi-estruturadas e estudo de recepção com trabalhadores da construção civil.

Neste artigo, apresentaremos os resultados do estudo de recepção de mensagens por trabalhadores da construção civil, visando a discussão dos aspectos relativos às temáticas abordadas nos impressos, confrontando-as com o ponto de vista dos trabalhadores. As análises realizadas decorrem do diálogo permanente com a literatura acerca das pesquisas de recepção na saúde 5 e com população rural 11, por esse grupo apresentar características semelhantes aos trabalhadores da construção civil, uma vez que na literatura revisada nenhuma referência de estudos de recepção de impressos sobre saúde do trabalhador foi encontrada. Outras fontes consultadas foram os estudos de avaliação de impressos e de processos comunicacionais na saúde 6,7,13,14,15.

\section{Procedimentos metodológicos}

Para o estudo de recepção, realizado no ano de 2002, foram constituídos dois grupos com trabalhadores da construção civil. Aconteceram quatro encontros, uma vez por semana, com uma hora de duração. Contamos, em média, com a participação de 12 trabalhadores por encontro. Os encontros foram realizados em dois canteiros de obra do Município do Rio de Janeiro, Brasil, situados na zona norte e zona sul, respectivamente. Entre os participantes da pesquisa, contamos com a presença de três trabalhadores que atuaram no Sindicato da Construção Civil, mas atualmente não apresentam nenhum tipo de vínculo com essa instância. Os trabalhadores são oriundos da zona norte do Município do Rio de Janeiro e da Baixada Fluminense, e a grande maioria sem alfabetização sistematizada.

No estudo de recepção de mensagens utilizamos a técnica de grupos de discussão 16, partindo das questões clássicas da comunicação social adaptadas para análise de impressos sobre saúde 12: para que servem os impressos? Para quem eles são dirigidos? O que discutem? Analisamos quatro materiais educativos, dois cartazes: "Programa de Saúde do Trabalhador" e "Conselho Estadual de Saúde do Trabalhador", e duas cartilhas: "Passaporte para Cidadania" e "Dermatose Profissional na Construção Civil Causada pelo Cimento".

$\mathrm{Na}$ análise desses materiais, adotamos o referencial da hermêutica-dialética, utilizando o método de análise temática, que resultou na classificação de dois núcleos de sentidos 16: 
"saúde" e "controle social", que foram agrupados a partir da organização e classificação das categorias empíricas. Os resultados são apresentados indicando-se a fala de cada trabalhador participante do grupo (Trabalhador $1=$ $\mathrm{T}: 1)$. Ressaltamos que apesar deste artigo enfatizar os sentidos atribuídos pelos trabalhadores aos materiais educativos, retomamos alguns dados do estudo que analisou a concepção do pólo emissor 17 de modo a enriquecer a compreensão do processo comunicativo em curso no PST. Os dados que se referem a esse estudo são indicados pela sigla (E:01-PST/RJ).

Neste artigo, pretendemos responder a questão: o que discutem os impressos? Visamos, especificamente promover um debate acerca da concepção que os trabalhadores apresentam sobre o processo saúde-doença relacionado com o trabalho e sobre a participação nas ações do PST, confrontando-a com a concepção encontrada nos impressos analisados.

\section{O que discutem os impressos: o ponto de vista dos trabalhadores da construção civil}

Apresentamos a seguir as categorias resultantes da análise dos temas dos impressos e da análise dos grupos de discussão com os trabalhadores da construção civil, sobre a pertinência e adequação das mensagens dos impressos. De um lado, o pólo emissor aborda os temas: (1) notificação de doenças e acidentes de trabalho; (2) divulgação institucional; (3) direitos dos trabalhadores; (4) agravos à saúde (riscos de acidentes e doenças no trabalho); e (5) medidas de segurança no trabalho, visando orientar, informar e prescrever normas ao pólo receptor para promover um debate ampliado de saúde 12,17. De outro, os trabalhadores abordam duas questões centrais: a saúde e o controle social.

\section{A saúde}

\section{- Medidas de segurança $x$ melhoria} das condições de trabalho e de vida

A discussão sobre medidas de segurança/prevenção no trabalho foi mediada pela análise das cartilhas "Passaporte para Cidadania" e "Dermatose Profissional na Construção Civil Causada pelo Cimento".

Iniciamos as discussões pela cartilha "Passaporte para Cidadania”, que apresenta alguns itens da Norma Regulamentadora 18 (NR18) 18, que dispõe sobre os direitos às condições de trabalho relativas: às adequadas instalações físicas (refeitórios, dormitórios, lavanderias e sa- nitários); à segurança no trabalho (uso de equipamentos de proteção individual - EPI); ao lazer. Objetiva informar e mobilizar o trabalhador para o cumprimento da norma. O estilo adotado na abordagem desses temas foi a utilização de imagens e do discurso direto, contribuindo para o confronto entre prescrito e real. Das discussões decorrentes das Figuras 1 e 2, os trabalhadores apontam alguns fatores que contribuem para a melhoria das condições de trabalho e de vida, entre eles: a alimentação, a segurança e a educação.

Vejamos alguns relatos: “(...) Um dia eu mandei a obra parar porque a empresa não estava dando café da manhã. E uma pessoa trabalhava há 50 metros de altura dizendo que estava tonta. Isso a empresa não gostou, mas acatou, que tinha que dar o café” (T:6). “(...) A saúde começa pela refeição. Eu acho que a gente deveria ser melhor alimentado, alguém tinha que ver isso, ninguém vê" (T:3).

Os trabalhadores relacionam essa situação com a existência ou não de interesse do patrão em suas condições de trabalho e saúde: “(...)

Figura 1

Trabalhador se alimentando em condições inadequadas.

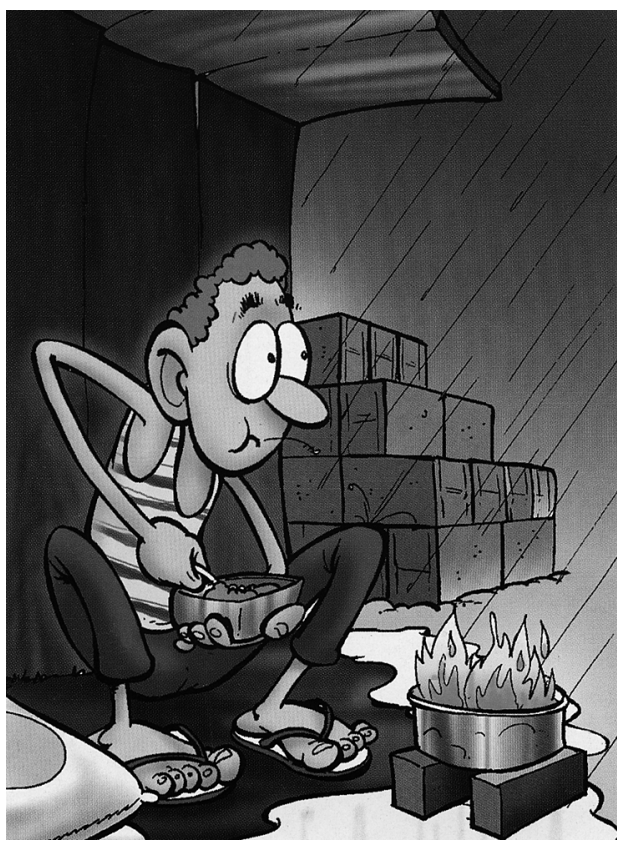

Por que tenho que comer assim?

Fonte: Fundação Jorge Duprat Figueiredo de Segurança e Medicina do Trabalho 25. 
Instalações de refeitório como determina a NR-18.

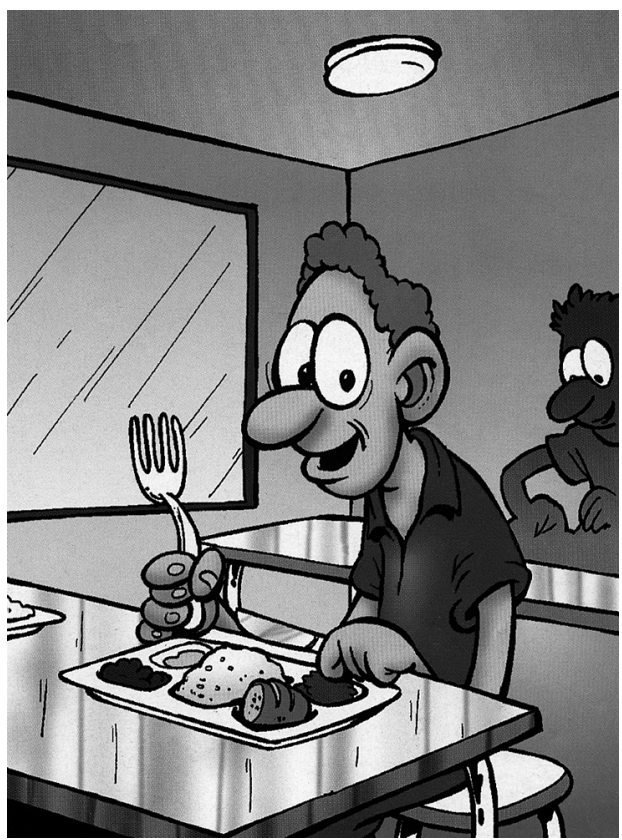

Se a NR-18 determina refeitórios amplos, arejados e limpos.

Fonte: Fundação Jorge Duprat Figueiredo de Segurança e Medicina do Trabalho 25.

Tem patrão que se preocupa em cuidar do trabalhador, mas esse é um no meio de cem" (T:6).

As discussões sobre as imagens que confrontam as condições de instalações sanitárias, lavanderias e dormitórios permitiram que os trabalhadores relatassem experiências anteriores em que trabalharam em péssimas condições. Contudo, ao confrontarem os aspectos citados com a realidade atual relatam que a empresa oferece boas condições.

Um outro aspecto abordado nos impressos refere-se às medidas de segurança/prevenção no trabalho por meio de mensagens que incentivam o uso de EPI e/ou equipamentos de proteção coletiva (EPC) (Figura 3). Os trabalhadores consideram que essas medidas de segurança protegem o trabalhador, mas devem ser adotadas tendo como base a melhoria e as transformações das condições de vida e de trabalho. Vejamos: “(...) O patrão perguntou como é que vive na favela? (...) Ali [o trabalhador] está
Figura 3

Trabalhador utilizando equipamento de proteção individual conforme prevê a NR-18.

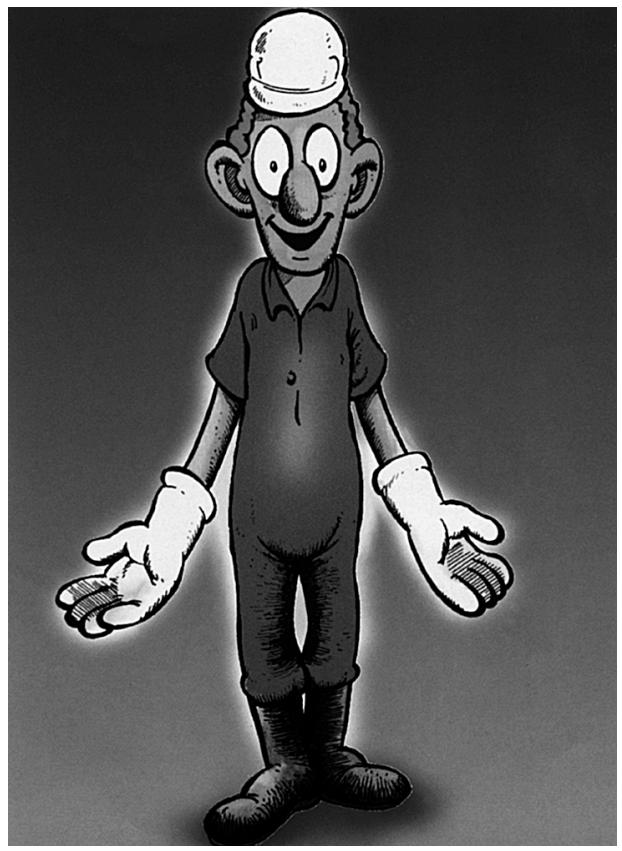

Se a NR-18 prevê uniforme e equipamento de proteção.

Fonte: Fundação Jorge Duprat Figueiredo de Segurança e Medicina do Trabalho 25.

bonitinho, depois ele vai para casa de chinelo, pegando ônibus cheio... são coisas muito difíceis de analisar. (...) Será que o importante é dar emprego e não cuidar dessa pessoa?" (T:6).

Os depoimentos demonstram que para o receptor, a segurança no trabalho se relaciona com todos os aspectos ligados à vida do trabalhador, em detrimento apenas de paramentálos com EPI e EPC. Os trabalhadores relacionam as questões de transporte, moradia e alimentação como pontos essenciais para garantir a segurança e promover a saúde no trabalho. Identificamos, na concepção de prevenção/segurança apresentada pelos trabalhadores, um conceito ampliado de saúde no trabalho que se fundamenta na inter-relação dos determinantes sociais com o processo de trabalho 1 .

De certa forma, essa visão contrapõe-se às mensagens dos impressos que tendem a demonstrar os efeitos dos produtos e dos ambientes de trabalho como fatores que interferem 
na saúde e, orientar o trabalhador sobre os cuidados necessários para a proteção/segurança no trabalho, por meio do uso de EPI e EPC. Identificamos nessa concepção a tendência à "culpabilização" e à "responsabilização" do sujeito diante do processo saúde-doença 5,12. Conforme Minayo, a questão dos equipamentos de segurança é um dos pontos reveladores da superexploração na construção civil, visto que "toda filosofia de segurança se acentua sobre o combate ao ato inseguro e não sobre a prevenção dos riscos" 19 (p. 29). Pois, na lógica empresarial, "perigoso não é o trabalho e sim o trabalhador" 19 (p. 29).

Consideramos que a prática comunicativa por impressos em curso nos PST se correlaciona com os princípios da educação sanitária tradicional 5 , cujo projeto educativo focaliza a doença, recorrendo à instrução e à orientação de indivíduos como base de modificação de comportamentos e de valores para a promoção da saúde. A Figura 4 e as frases a seguir evidenciam esse ideário educativo: "Para proteger sua pele, siga estas recomendações” 20. "Evite trabalhar de bermuda. Use calça comprida. Trabalhar com sandália hawaiana prejudica sua pele. Use bota de couro ou de borracha" 20. "A proteção das mãos e dos pés e a boa higiene são importantes para se evitarem estas dermatoses. Siga as recomendações aqui indicadas e boa saúde" 20.

Alguns depoimentos expressam a opinião dos trabalhadores sobre essas mensagens: “(...) Eu já vi isso com um amigo meu, e foi por causa do cimento, ele não se preocupava em colocar a luva e nem a bota, na época nem tinha muito essas coisas de luva e de bota" (T:8). "Eu criei uma alergia porque tem que mexer o negócio [refere-se à massa] e lavar as mãos. O cara vai mexer num lugar que não tem água perto (...) água ali para você lavar ali a mão (...) para parar de se coçar" (T:9).

Os trabalhadores discutem a concepção monocausal de segurança no trabalho, consideram como um fator determinante para melhoria das condições de trabalho e de vida o fomento de uma política de educação e de capacitação para os trabalhadores. De modo que, tal investimento, poderia contribuir para o entendimento, por parte do trabalhador, sobre a importância do uso de EPI e do manuseio e o controle dos EPC. Pois segundo os relatos dos trabalhadores, o que adianta dar luvas, botas, cintos, instalar prancha e gruas, se o trabalhador não sabe usar e nem manusear os equipamentos? E ainda, muitas vezes nem os conhece, pois não fazem parte de sua cultura e seu modo de vida.

\section{Figura 4}

A expressão da dermatose ocupacional na construção civil.

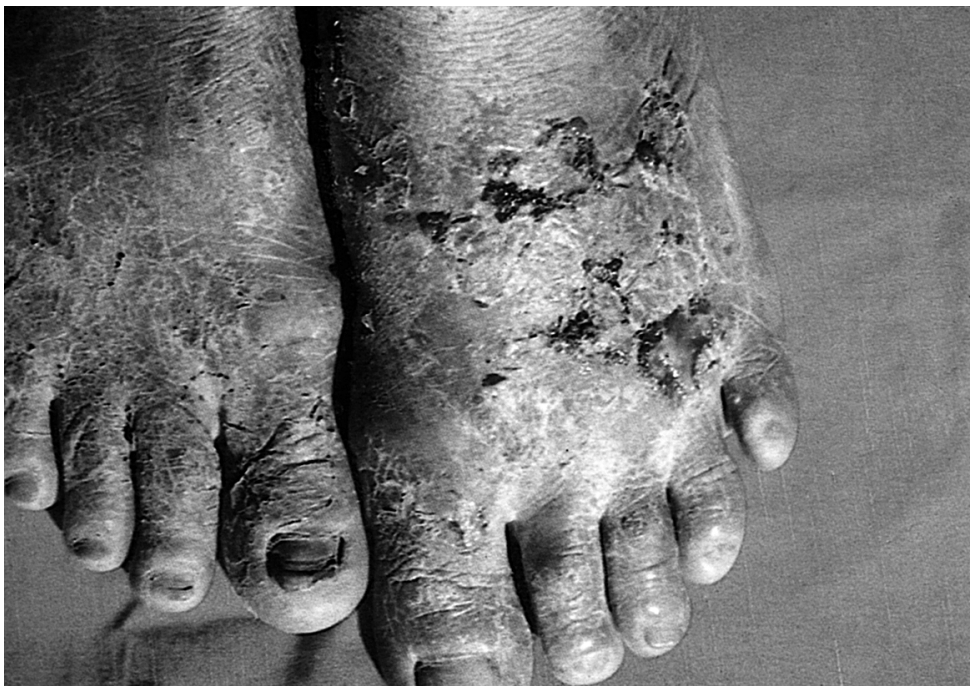

Fonte: Fundação Jorge Duprat Figueiredo de Segurança e Medicina do Trabalho 20.

Vejamos os relatos: "Às vezes um [trabalhador] vem do Nordeste e ele não tem o hábito de usar sapatos, quando ele chega aqui não há um estudo feito para o trabalhador [refere-se ao treinamento]. Então é dito na gíria da construção civil que aquela pessoa ele é um 'barriga verde.' (...) 'Barriga verde', que ele não sabe o que é uma obra, ele está vindo [do Nordeste] é acostumado a ver mato, capinar, aí chega numa obra o cara diz: 'ó, calça uma bota!' Dá uma bota para ele, com meia hora ele está andando de ponta de pé. Aquilo causa um problema na saúde dele. Se você o educasse a calçar a bota, como ele está mudando de hábito. Mas eu não vejo nenhuma empresa investir nisso, educar" (T:6). “(...) O trabalhador chega numa obra ele não sabe o que é uma prancha. Eo risco que causa uma prancha é muito grave, não tem um grupo para ensinar, aí eu critico o sindicato" (T:4).

Os trabalhadores atribuem a essa situação o pouco investimento por parte dos empresários e também dos sindicatos, em uma política consistente de treinamento em segurança/prevenção no trabalho. Eles reconhecem essa ausência de uma política de educação como um descaso, uma desvalorização e uma forma de negar seu direito de cidadão e de sujeito-trabalhador: "Hoje na construção civil, o trabalhador é adulto abandonado. (...) O trabalhador tem medo, tem vergonha" (T:6). "Somos os escravos 
da sociedade” (T:4). “(...) [o operário da construção civil] não se valoriza a si próprio. Por isso, que a gente vai cada vez piorando. Tem que se valorizar mais” (T:10). “(...) O pessoal que trabalha em obra muito tem vergonha até de dizer que trabalha em obra” (T:6). “(...) É porque a obra tem aquela cultura que o operário da construção civil é um pessoal sem conhecimento, muitos analfabetos. Então as pessoas acham que são inferiores" (T:3).

Esses depoimentos evidenciam uma questão estrutural intrínseca às relações de produção, que se refere à condição de assujeitamento, via "desqualificação" e "desvalorização" do saber do operário, às imposições da sociedade capitalista. Nos relatos acima, os trabalhadores colocam que a educação poderia ser um auxílio/instrumento para a adesão dos trabalhadores ao uso de EPI/EPC, demonstrando a reprodução da lógica utilitária da educação, isto é, recorre-se às metodologias educativas para reproduzir a racionalidade do poder hegemônico: educar para instruir para prevenir e para produzir. Isso permite a reprodução e perpetuação do conflito entre as relações sociais.

Por outro lado, quando os trabalhadores evidenciam a situação de abandono e escravidão a que estão submetidos, demonstram com clareza o lugar que o trabalhador ocupa nas relações socais. Podemos dizer que as palavras: "escravos", "abandonado", "vergonha”, "sem direito" e "analfabeto" evidenciam a questão da identidade do trabalhador; com base em Minayo 19 consideramos que essas palavras podem expressar o sentimento de pertencer a um determinado grupo, ou não, no interior da organização social da produção.

A esse respeito, Minayo 19 aponta que nos canteiros de obras há uma pluralidade de identidades, sendo uma delas a "identidade pela negação" 19 (p. 33) aquela onde os "peões bus cam ocultar quem são" 19 (p. 33). As causas que constituem esta "identificação negativa" referem-se à discriminação cultural do setor (as pessoas são "nordestinas", "sem estudo", de “áreas rurais”); à discriminação por baixos salários e a superexploração, o que contribui para que muitos trabalhadores busquem outros setores produtivos.

\section{- Informação dos direitos x o cumprimento dos direitos}

A problemática dos direitos dos trabalhadores foi abordada com mais cuidado na análise da cartilha "Passaporte da Cidadania". As discussões dos trabalhadores enfatizam como uma questão de saúde no trabalho e um direito, a garantia de possuírem a carteira de trabalho assinada. Como explicitado a seguir: " $A$ pessoa não ter carteira assinada, o cara se preocupa que não tem direito a nada dessas coisas, tudo é preocupação para ele” (T:2). “(...) Para um operário a carteira assinada é tudo” (Т:3). “(...) A preocupação é o pior mal que você pode ter (...) e gera doença” (T:2). “(...) Se o cara tiver um acidente com afastamento do trabalho, o cara não vai ter seguro [quando não tem carteira assinada]" (T:9). "[refere-se à carteira assinada] $E$ uma segurança (...) o cara se sente seguro" (T:7).

Essa preocupação foi central na falas dos trabalhadores, ao passo que, nas mensagens ofertadas, as questões relacionadas com os vínculos empregatícios sequer foram abordadas.

A partir da análise das cartilhas, consideramos que os trabalhadores reconheceram nas temáticas analisadas situações pertinentes à sua realidade, o que contribuiu para a discussão crítica das relações entre saúde e trabalho. No reconhecimento das mensagens abordadas, identificamos que o uso do discurso direto e claro auxiliou na compreensão do texto, e o uso de imagens correspondentes à realidade permitiu a identificação de características específicas às condições de vida e trabalho na construção civil. Esses elementos contribuem para uma melhor comunicação com o leitor 11,14.

\section{O controle social}

\section{- Inclusão dos trabalhadores nas ações de fiscalização x não inclusão}

A temática do controle social decorre da avaliação dos cartazes: "Programa de Saúde do Trabalhador" e "Conselho Estadual de Saúde do Trabalhador", ambos produzidos por um dos PST do Estado do Rio de Janeiro, visando à divulgação institucional e informar as ações realizadas por essas instâncias. Mediante a leitura desses cartazes, perguntamos aos trabalhadores se já haviam participado das ações de fiscalização dos PST pertencentes ao Ministério da Saúde.

De um modo geral, a resposta foi que sequer conheciam esses programas, apenas um trabalhador relatou que conhecia um dos PST do Estado do Rio de Janeiro, devido à sua inserção há um tempo atrás na diretoria do Sindicato da Construção Civil, momento em que teve a oportunidade de participar de discussões e propostas desse programa. Vejamos: “(...) [refere-se aos PST] Porque a gente só tomou ciência foi agora, a partir dessa reunião. Porque se você falasse com a gente na rua: Você sabe que existe, ninguém sabia” (T:3). “(...) Para usar esse pro- 
grama deve ter que pagar. Deve ser, assim, igual um plano de saúde" (T:11).

Os relatos acima, evidenciam o desconhecimento da existência da atenção à saúde do trabalhador no SUS, seja por meio do acesso dos trabalhadores aos PST ou pelo atendimento na rede básica de saúde. A problemática da cobertura da rede básica de saúde à população trabalhadora existe desde o início da inclusão da saúde do trabalhador pelo setor saúde ${ }^{2}$.

Com base nessas discussões foi possível esclarecer sobre o funcionamento e propostas dos PST. De um modo geral, os trabalhadores demonstraram interesse e apoio às idéias-chave preconizadas para o desenvolvimento da atenção à saúde do trabalhador no SUS, como demonstrado no relato a seguir: “(...) Eles têm que participar mais com gente. (...) Eu acho que até eu não vi, eu não conheço e a gente precisa conhecer. Esse poder precisa sair da capa, vamos dizer assim, sair de onde está e vim junto ao operário" (T:4).

Nos impressos analisados 12,17, a temática da participação dos trabalhadores nas ações dos PST é recorrente. Todavia, a partir da opinião dos trabalhadores fica evidente que a participação representa mais um desafio colocado em questão, do que propriamente uma realidade vivida nos programas. Atribuímos essa contradição, entre outros motivos, ao pouco investimento na atenção à saúde do trabalhador. Visto que, em geral, os PST funcionam com um número restrito de profissionais, o que impossibilita a ampliação dos serviços de saúde do trabalhador na rede pública e ações mais continuadas junto aos trabalhadores 12 .

Os trabalhadores mencionam, com muita freqüência, as intervenções do Ministério do Trabalho e Emprego, discutem que não participam das ações de fiscalização do ministério e apresentam certo descrédito ao trabalho realizado pelos fiscais que atuam nesse órgão. Vejamos: “(...) Agora sinceramente cara, eu não confio mais no Ministério do Trabalho, até na terceirização eles são culpados” (T:4). “(...) O Ministério tinha que participar mais com o operário, $t i$ nha que participar, saber o que está havendo dentro da obra. O Ministério tem que participar, não está participando" (T:4) (grifos nossos).

Mediante as contradições referentes à promoção de saúde no trabalho, especificamente as ações de fiscalização dos processos de trabalho, nos cabe perguntar: como mudar os ambientes ou processos de trabalho deixando à parte aqueles que têm o domínio e o conhecimento da realidade, do saber fazer diante dos processos de trabalho em que estão inseridos?

\section{Existência do controle social $x$ propostas de novas formas de organização do trabalhador}

A problematização do controle social surge a partir do contato dos trabalhadores com os cartazes citados, por meio de mensagens que abordam a atuação do controle social em diversos ramos produtivos, entre eles, o da construção civil.

No primeiro momento, o que mobilizou mais a atenção dos trabalhadores foi uma fotografia de pessoas que compõem o Conselho Estadual de Saúde do Trabalhador (CONSEST), ou seja, os representantes do controle social. Vejamos um dos efeitos dessa mensagem: "Mas isso aí só existe no cartaz, eu nunca ouvi falar. (...) Primeiro, eu acho que eles se organizam entre eles mesmos. (...) Isso aí é igual festa de bacana, pobre chega na porta e volta" (T:6).

Mediante esse relato, novos debates surgiram acerca do que é o controle social, especificamente o que é o CONSEST. Algumas perguntas são feitas: "No caso o cara vai procurar esse conselho aí, ele tem que ser sindicalizado?" (T:11). "Por exemplo, uma pessoa que trabalha na construção civil, ela sofre um acidente e a empresa não acata com a sua doença, uma lesão que ele causou dentro da construção civil. Se ela procurar esse conselho, ele vai ter resultado ou ele vai lá só para ver [as pessoas] palestrar ou comes e bebes?" (T:6). "Só que o operário da construção civil só pode participar se ele procurar também, né?" (T:11).

Esses relatos demonstram o desconhecimento sobre a existência do CONSEST e suas atribuições. Nesses discursos, há implícito a pouca credibilidade conferida à atuação dos representantes do conselho e o poder de resolução frente às demandas trazidas por trabalhadores.

No decorrer da discussão um outro trabalhador explica o que é o CONSEST e preocupado com o entendimento a respeito do conselho analisa: “(...) Aqui eu percebi que algumas pessoas pensam que o conselho é como se fosse uma agência, um hospital que eles vão lá para serem atendidos. O conselho é para pensar política de saúde. (...) [o papel do conselho] não está claro porque o conselho não consegue sair daquela sala, eu acho que o conselho não se faz presente" (T:12).

Baseando-se nesses depoimentos, compartilhamos a definição de Sposati \& Lobo 21 (p. 373) que "o espaço do controle social ainda que institucionalizado, não é meramente administrativo, é um espaço político que põe em cena interesses, imaginário, representações. Este es- 
paço é uma situação de partida, e não de chega$d a$ ". Sendo assim, consideramos que embora o CONSEST seja um mecanismo de participação coletiva nas ações de saúde do trabalhador, ainda apresenta pouco alcance junto aos segmentos que representa.

Um outro fator que contribuiu para essa visão atribuída ao CONSEST - "festa de bacana", foi a utilização da fotografia dos atores que representam essa instância. De um lado, o pólo emissor atribui a esse recurso um motivo de aproximação com o pólo receptor, como expressa um de nossos entrevistados 17: "uma coisa que usei e foi tuchê foi a fotografia. (....) Quando eu dou uma palestra que eu mostro esse retrato do CONSEST os trabalhadores identificam [nome de um sindicalista], identificam os trabalhadores, os técnicos, identificam alguém" (E:01-PST/RJ).

De outro, apreendemos do debate junto aos trabalhadores que esse recurso acentuou a distância entre os pólos, emissor-receptor, visto que os trabalhadores não reconheceram esses atores como representantes de sua categoria e conseqüentemente de seus interesses.

Analisamos, a partir do ponto de vista dos trabalhadores, se a utilização de fotografias consistia em um impeditivo para a identificação entre os interlocutores no processo comunicativo mediado. Apresentamos um impresso que contém fotos de trabalhadores em diferentes postos de trabalho realizando várias atividades. Identificamos que essa estratégia teve um efeito positivo, despertando a curiosidade e o interesse no contato com o material.

Um outro elemento importante a se destacar sobre a utilização de imagens ou desenhos, refere-se ao cartaz "Programa de Saúde do Trabalhador" em que o controle social aparece representado na Figura 5. Perguntamos aos trabalhadores o que essa figura representava, as interpretações foram diversas: "Parece até uma equipe de vôlei" (T:6). "Está tudo desnutrido" (T:10). "Mostra um monte de gente indo para um lugar só” (T:6). "Mas não mostra gente não, mostra uns robozinhos" (T:3). "Para mim está me lembrando uma família” (T:7). "Um soldado marchando" (T:10).

Mediante esses relatos, discutimos que o propósito do desenho era o de representar o trabalhador, especificamente, o controle social. Os trabalhadores relataram que essa idéia não ficou clara e apresentaram algumas sugestões: "Se fosse para representar o trabalhador, devia pôr uma enxada no ombro e uma foice" (T:1). "Mas isso é um trabalhador rural" (T:3). Diante dessa discussão, perguntamos como seria possível representar o trabalhador da cons- trução civil, a resposta foi: "Mostra um cara com uma picareta" (T:2).

Identificamos a partir desses relatos que os ícones "fotografia dos representantes de programas" e os "bonequinhos", considerados elementos de representação, não se constituíram em "objetos referentes", ou seja, "que fazem referência a” 22 , no caso, a idéia de controle social. Desse modo, essas imagens não formam elemento de um "signo", ou seja, não constituem um "significado" da idéia de controle social. Segundo Bordenave 23 (p. 67) "o significado dos signos não está nos próprios signos, nem nos objetos, mas nos conceitos ou imagens formados na mente das pessoas".

Com base nesse conceito, consideramos que a interpretação dos trabalhadores "festa de bacana" sobre a fotografia dos atores que constituem o CONSEST, evidencia as diferenças existentes nas relações sociais de produção, de modo que os trabalhadores não se incluíram como uma das partes desse segmento social.

Em relação ao ícone dos "bonequinhos", as semelhanças estabelecidas, pelo pólo receptor, giram em torno da representação dos "bonecos" como "humanos", associando a eles elementos da realidade: "está desnutrido", "parece uma família", "uma equipe de vôlei”. Essas expressões dizem respeito ao campo semântico e cultural no qual estão inseridos, ou seja, temas como desnutrição, família e esporte estão mais próximos ao seu contexto de vida do que a questão do controle social como a apresentada no cartaz.

Na pesquisa de recepção com população rural, Araújo 11 discute que para os camponeses a utilização de desenhos nos materiais educativos impressos possui o mesmo valor que uma fotografia, isto é, apresentam uma relação de correspondência com a realidade. Para uma melhor interlocução com o leitor, recomendase que os desenhos ofereçam elementos que sejam conhecidos e relevantes. Ressalta-se que caricaturas dificultam a compreensão do leitor favorecendo a incomunicabilidade 11 .

Em referência às interpretações do pólo receptor, citadas acima, como: "Mostra um monte de gente indo para um lugar só” (T:6); “Mas não mostra gente não, mostra uns robozinhos" ( T:3), nos sugerem que há no imaginário, do pólo emissor, a idéia do "trabalhador em série" e de "homem máquina", decorrente da forte cultura midiática das décadas de 1930 e 1950, pautada no modelo informacional, em que surgem os conceitos de "massa" e "grupos" 8,9.

Sendo assim, consideramos que a prática comunicativa dos programas apresenta semelhanças com o modelo informacional que tem 
como objetivo a comunicação de massa. No campo da saúde esse modelo ainda hegemônico 16 é amplamente utilizado por trabalhadores de saúde, mesmo sem intencionalidade. $\mathrm{O}$ estudo de revisão sobre impressos hospitalares 13 identifica na utilização de impressos a primazia da comunicação monológica e instrumental, que visa influenciar seus destinatários para aderirem aos projetos institucionais, reforçando a lógica vertical de comunicação.

Um outro fator que contribui para o descrédito, por parte dos trabalhadores referente ao controle social, está na pouca legitimidade conferida ao sindicato da categoria. Vejamos: "Eu fui ao sindicato duas vezes para receber indenização" (T:7). "Que existe eu sei, porque eu pago todo mês, vem descontando do meu pagamento" (T:8). "Olha eu gostaria de conversar com pessoa que tivesse poder e autoridade para resolver parte de nossos problemas. Mas [o sindicato] não tem poder é lamentável é lamentável, autoridade que não tem poder para mim não é autoridade" (T:4).

Apreendemos desses relatos que os trabalhadores conhecem o sindicato e que há uma distância entre esses dois segmentos. Isso favorece, a nosso ver, que os trabalhadores não se sintam representados por seus pares, de modo que não identifiquem de imediato os trabalhadores que atuam no CONSEST como possíveis aliados na luta por melhores condições de trabalho e de vida.

Um fato relevante surgido do debate relativo às contradições do movimento sindical, explicitadas pelos trabalhadores, foi a discussão de propostas de mudanças da configuração da equipe da Comissão Interna de Prevenção de Acidentes de Trabalho (CIPA), visando a novas formas de organização sindical. Vejamos: “(...) $a$ construção por canteiro de obra, de uma espécie de Comitê de Segurança e Saúde do Trabalho (...) composto por três pessoas, um representante da empresa, um representante dos trabalhadores. (...) Esses comitês vão ter que gerir os processos de saúde no local de trabalho. Não é só cinto, bota e capacete, e sim processo de saúde" (T:12).

Um outro trabalhador intervem: “(...) Mas acontece se não tiver uma fiscalização rigorosa do MT, não vai acontecer nada. [Porque os empresários] querem construir barato, escravizar mão-de-obra, [querem] a terceirização [pois] vêm para cá os trabalhadores e não assina carteira de ninguém. Então companheiro, não adianta formar CIPA para cuidar de nossa segurança, mas não cuidar de nossos direitos" (T:4).

Esses relatos correspondem às contradições vividas no cotidiano de trabalho dos operários da construção civil. Consideramos que essas
Figura 5

"Bonecos" enfileirados: ícones do controle social.

Controle social

Conselho Estadual de Saúde do Trabalhador - CONSEST

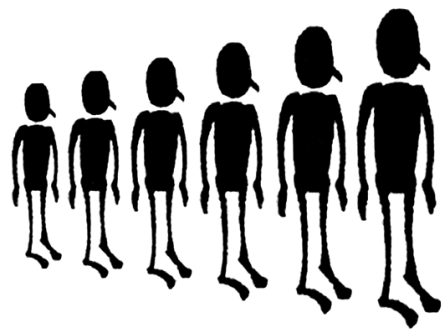

Atuante desde 1991

Composto de 24 sindicatos

e 12 instituições públicas.

Função:

Formular, acompanhar e avaliar a Política de Saúde do Trabalhador do Estado do Rio de Janeiro.

Fonte: Programa de Saúde do Trabalhador (Secretaria Estadual de Saúde Rio de Janeiro).

contradições são intrínsecas às relações entre capital vs. trabalho, isto é, "o próprio processo de trabalho é um campo de luta. (...) Aí se instaura ao mesmo tempo, que a divisão organizada pelo capital, o companheirismo entre os operários e a resistência à dominação" 19 (p. 35).

Portanto, consideramos que as ações da saúde do trabalhador constituem uma possibilidade de intervenção diante dos problemas identificados, uma vez que essa abordagem está vinculada às políticas de caráter social e econômico, e tem como princípio a busca de estratégias coletivas para o enfrentamento das questões intrínsecas ao conflito capital-trabalho. Além disso, busca viabilizar "um desenvolvimento sustentável, fundado no resgate da dívida social e na revitalização e revalorização do caráter público do Estado para assegurar a efetividade dos direitos de cidadania" 1 (p. 32).

\section{Considerações finais}

A estratégia de utilização de impressos como mediação vem oferecendo bons resultados 5,12, 17,24 ao favorecer a inclusão de diversos interlocutores na produção de conhecimentos, facilitando a problematização da realidade.

Dessa forma, os materiais educativos em saúde são componentes do processo de aprendizagem, e quando usados de maneira participativa e interativa podem facilitar a produção de conhecimento por seus leitores 14. Por isso, as informações escolhidas para compor um material educativo devem fornecer elementos 
para a tomada de decisões 11 , em detrimento de prescrever padrões de comportamentos e atitudes.

Nesse sentido, consideramos que a análise de materiais educativos por seus destinatários significa um lugar privilegiado de negociação de sentidos, sobretudo, representa um espaço de apreensão dos modos de viver de diferentes grupos sociais.

\section{Resumo}

Trata-se de um estudo de recepção de mensagens por trabalhadores da construção civil. Utilizamos como mediação os materiais educativos (cartazes, folders $e$ cartilhas) produzidos pelo Ministério da Saúde e Ministério do Trabalho e Emprego. Realizamos dois grupos focais, em dois canteiros de obra no Município do Rio de Janeiro, Brasil, para a análise de quatro materiais educativos; utilizamos análise temática. Apresentamos o ponto de vista dos trabalhadores sobre os temas discutidos nos impressos, classificados em dois núcleos de sentidos: saúde e controle social. Discutimos que os trabalhadores apresentam uma visão ampliada de saúde à medida que inclui os determinantes sociais ao processo saúde-doença. Identificamos a pouca participação dos trabalhadores nas ações de fiscalização dos processos de trabalho, e o desconhecimento das ações de saúde do trabalhador desenvolvidas pelo Ministério da Saúde. Concluímos que a análise de materiais educativos por seus destinatários, representa um lugar privilegiado de negociação de sentidos e de apreensão dos modos de viver de grupos específicos. Sugerimos a realização de atividades educativas que utilizem os impressos como mediação para motivar a problematização do processo saúde-doença.

Impressos Avulsos; Saúde Ocupacional; Indústria da Construção

\section{Colaboradores}

A. Kelly-Santos realizou a revisão da literatura, coleta de dados, análise dos dados e dos resultados, redação do artigo e revisão final. B. Rozemberg participou da análise dos resultados, redação e revisão do artigo final.
Sendo assim, no âmbito dos processos comunicativos do PST, identificamos a importância de propor modelos comunicacionais que busquem a interação humana fundada no diálogo 7 , mas, sobretudo, que visem problematizar as condições sociais e institucionais $11 \mathrm{em}$ que são produzidas as práticas comunicativas, à medida que os materiais educativos são lugares de interlocução 11, onde os interlocutores reconhecem e legitimam seus espaços de fala $\mathrm{e}$ constroem e/ou modificam suas práticas.

\section{Referências}

1. Minayo-Gomez C, Thedim-Costa SMF. A construção do campo da saúde do trabalhador: percurso e dilemas. Cad Saúde Pública 1997; 13 Suppl 2:21-32.

2. Lacaz FC. Saúde do trabalhador: um estudo sobre as formações discursivas da academia, dos serviços e do movimento sindical [Tese de Doutorado]. Campinas: Universidade Estadual de Campinas; 1996.

3. Dias EA. Atenção à saúde dos trabalhadores no setor saúde (SUS), no Brasil: realidade, fantasia ou utopia? [Tese de Doutorado]. Campinas: Universidade Estadual de Campinas; 1994

4. Spedo SM. Saúde do trabalhador no Brasil: análise do modelo de atenção proposto para o Sistema Único de Saúde (SUS) [Dissertação de Mestrado]. Campinas: Faculdade de Ciências Médicas, Universidade Estadual de Campinas; 1998.

5. Rozemberg B. A intransparência da comunicação: crítica teórico-metodológica sobre a interação do saber e das práticas médicas e experiência das populações de áreas endêmicas de esquistossomose [Tese de Doutorado]. Rio de Janeiro: Escola Nacional de Saúde Pública, Fundação Oswaldo Cruz; 1995.

6. Rozemberg B, Silva APP, Vasconcellos-Silva PR. Impressos hospitalares e a dinâmica de construção de seus sentidos: o ponto de vista dos profissionais de saúde. Cad Saúde Pública 2002; 18:1685-94.

7. Baillie L, Basset-Simith J, Brouggton S. Using communicative action in the primary prevention of cancer. Health Educ Behav 2000; 27:442-53.

8. Fausto-Neto A. O indivíduo apesar dos outros: modos de descrever, modos de construir o mundo da recepção. In: Seminário de Avaliação das Ações de IEC. Brasília: Ministério da Saúde; 1999. p. 1-15. 
9. Sousa MW. Recepção e comunicação: a busca do sujeito. In. Sousa MW, organizador. Sujeito, o lado oculto do receptor. São Paulo: Editora Brasiliense; 1995. p. 13-38.

10. Barbero-Martín J. América Latina e os anos recentes: o estudo da recepção em comunicação social. In. Sousa MW, organizador. Sujeito, o lado oculto do receptor. São Paulo: Editora Brasiliense; 1995. p. 39-68.

11. Araújo I. Materiais educativos e produção dos sentidos na intervenção social. In: Vargas EP, organizador. Educação, comunicação e tecnologia: interfaces com o campo da saúde. Rio de Janeiro: Editora Fiocruz; no prelo.

12. Kelly-Santos A. Análise do processo comunicativo mediado por impressos: o ponto de vista dos atores dos Programas de Saúde do Trabalhador [Dissertação de Mestrado]. Rio de Janeiro: Escola Nacional de Saúde Pública, Fundação Oswaldo Cruz; 2003.

13. Vasconcellos-Silva PR, Riviera FJU, Rozemberg B. Próteses de comunicação e alinhamento comportamental sobre impressos hospitalares. Rev Saúde Pública 2003; 37:531-42.

14. Nash J. Learning materials: their use and evaluation. Lepr Rev 1999; 70:254-60.

15. Cardoso JM. Comunicação, saúde e discurso preventivo: reflexos a partir de uma leitura das campanhas nacionais de AIDS veiculadas pela TV (1987-1997) [Dissertação de Mestrado]. Rio de Janeiro: Escola de Comunicação, Universidade Federal do Rio de Janeiro; 2002.

16. Minayo MCS. O desafio do conhecimento: pesquisa qualitativa em saúde. São Paulo: Editora Hucitec/Rio de Janeiro: ABRASCO; 2000.
17. Kelly-Santos A, Rozemberg, B. Comunicação por impressos na saúde do trabalhador: a perspectiva das instâncias públicas. Ciênc Saúde Coletiva 2005; 10:929-38.

18. Ministério do Trabalho e do Emprego. Condições de trabalho e meio ambiente na indústria da construção: NR-18. Brasília: Ministério do Trabalho e Emprego; 1996.

19. Minayo MCS. Olhando através dos andaimes e tapumes. Proposta 1987; 33:22-38.

20. Ali SA. Dermatose profissional na construção civil causada pelo cimento. Brasília: Fundação Jorge Duprat Figueiredo de Segurança e Medicina do Trabalho; 1992.

21. Sposati A, Lobo E. Controle social e políticas de saúde. Cad Saúde Pública 1992; 8:366-78.

22. Peres F, Rozemberg B, Moreira J, Rabello S. O processo de comunicação rural sobre agrotóxicos em área rural do Estado do Rio de Janeiro. Rev Saúde Pública 2001; 35:21-37.

23. Bordenave JD. O que é comunicação? 13ạ Ed. São Paulo: Editora Brasiliense; 1982.

24. Souza KR, Rozemberg B, Kelly-Santos A, Yasuda $\mathrm{N}$, Sharapin M. O desenvolvimento compartilhado de impressos como estratégia de educação em saúde junto a trabalhadores de escolas da rede pública do Estado do Rio de Janeiro. Cad Saúde Pública 2003; 19:495-504.

25. Fundação Jorge Duprat Figueiredo de Segurança e Medicina do Trabalho. Passaporte para a cidadania. Brasília: Fundação Jorge Duprat Figueiredo de Segurança e Medicina do Trabalho; 1996.

Recebido em 04/Nov/2004

Versão final reapresentada em 12/Ago/2005

Aprovado em 02/Set/2005 